IZA DP No. 5456

Public Housing and Residential Segregation of Immigrants in France, 1968-1999

Gregory Verdugo

January 2011 


\title{
Public Housing and Residential Segregation of Immigrants in France, 1968-1999
}

\author{
Gregory Verdugo \\ Banque de France \\ and IZA
}

\section{Discussion Paper No. 5456 \\ January 2011}

IZA

P.O. Box 7240

53072 Bonn

Germany

Phone: +49-228-3894-0

Fax: +49-228-3894-180

E-mail: iza@iza.org

Any opinions expressed here are those of the author(s) and not those of IZA. Research published in this series may include views on policy, but the institute itself takes no institutional policy positions.

The Institute for the Study of Labor (IZA) in Bonn is a local and virtual international research center and a place of communication between science, politics and business. IZA is an independent nonprofit organization supported by Deutsche Post Foundation. The center is associated with the University of Bonn and offers a stimulating research environment through its international network, workshops and conferences, data service, project support, research visits and doctoral program. IZA engages in (i) original and internationally competitive research in all fields of labor economics, (ii) development of policy concepts, and (iii) dissemination of research results and concepts to the interested public.

IZA Discussion Papers often represent preliminary work and are circulated to encourage discussion. Citation of such a paper should account for its provisional character. A revised version may be available directly from the author. 


\section{ABSTRACT}

\section{Public Housing and Residential Segregation of Immigrants in France, 1968-1999*}

This paper studies the evolution of the residential segregation of immigrants between and within urban areas in France from 1968 to 1999 using census data. During this period, European and non-European immigrant segregation followed diverging trends. This paper documents the large increase in public housing participation rates of non-European immigrants after 1980 and highlights how public housing participation is related to contemporary segregation. At the macro-geographical level, results indicate a decrease in the concentration of immigrants across urban areas, showing a lower concentration of nonEuropean immigrants living in public housing across urban areas. Within cities, national origin segregation was predominant until 1968 for all groups and declined afterward, particularly for European immigrants. For non-European immigrants participating in public housing, the decline in segregation by national origin has been counterbalanced by an increase in regional segregation. Immigrants of different national origins have increasingly clustered in the same public housing neighborhoods. In 1999, immigrants in public housing experienced higher segregation levels than immigrants in private housing, particularly non-European immigrants. I find no relationship between differences in average arrival year and differences in segregation levels across immigrant groups.

JEL Classification: J61, J18, J15

Keywords: $\quad$ public housing, immigration, segregation, France

Corresponding author:

Gregory Verdugo

Banque de France

DGEI-DEMS-SAMIC

31 rue Croix-des-petits-champs

75049 Paris Cedex 01

France

E-mail: gregory.verdugo@banque-france.fr

\footnotetext{
* The author wishes to acknowledge the INSEE that provided the underlying data making this research possible. I particularly thank Jean-François Royer from Crest Insee for his help with the 1999 census data and Alexandre Kych from the Centre Maurice Halbwachs for his help with other censuses used in the paper. I also thank three referees and the editors for insightful comments. Data from the 1968, 1975, 1982, 1990, 1999 censuses are available for researchers from the Centre Maurice Halbwachs. Restricted data from the 1999 French census used in this paper are confidential but the author access is not exclusive. For additional information, contact the author. The views expressed in this paper do not necessarily reflect the views of the Banque de France.
} 


\section{Introduction}

The riots of 2005 in France highlighted the housing conditions of many first- and second-generation immigrants in public housing suburbs. Following these events, social observers have been increasingly concerned about the consequences of segregation in France, arguing that the poorest part of the population, particularly some immigrant groups and their descendants, are becoming increasingly concentrated in public housing suburbs. However, quantitative research on the evolution of segregation has been relatively rare until today which leaves unexplored the impact of housing policies, particularly public housing, on segregation. Public housing is a source of concern for immigration policymakers as the concentration of immigrants is very high in many suburban public housing developments in France, specifically, and in Europe more generally. Also, the participation rates of some groups of immigrants in public housing are much higher than the rate of natives, as I describe below.

In this paper, I describe the evolution of immigrant segregation in France over a period of 30 years from 1968 to 1999, which is the maximum time period for which census data at the individual level are available. The objective of this paper is to highlight the new and specific aspects of contemporary segregation of immigrants and to emphasize its links with the increase in public housing participation observed over the period. I document that the increase in public housing supply in France during the 1960s and the 1970s was followed by a large increase in public housing participation by non-European immigrants after the 1980s. According to the 1999 census, while $15 \%$ of natives lived in public housing in 1999, the participation rate was close to $50 \%$ for immigrants from the Maghreb. Public housing participation directly affects and influences the locations of immigrants within and potentially across urban areas and thus influences different aspects of segregation.

I try to derive whether the gap between the participation rates of immigrants and natives can be explained by differences in household characteristics. I find that most of the gap in participation rates between non-European immigrants and natives cannot be explained by differences in observable characteristics of households or by the fact that immigrants live in municipalities with a larger public housing supply. Differences in participation in public housing thus reflect specific constraints or tastes that made public housing participation more attractive for non-European immigrants than for natives during the period. In the rest of this paper, I highlight the differences in segregation levels experienced by public housing inhabitants compared to other segments of the population. 
To quantify the evolution of segregation, I construct several indices of segregation at different geographical levels to capture different aspects of the change in the spatial distribution of immigrants in France over the study period. For the specific period under study, it is particularly important to distinguish between immigrants from different origins as the evolution of segregation differs widely between European and non-European groups. Thus, the rest of this paper describes the evolution of segregation of immigrants by regional and national origins. Because of space limitations, I report results by national origins for the following six largest groups of immigrants during the period: Algeria, Morocco and Tunisia for the Maghreb region and Italy, Spain and Portugal for Southern Europe.

I first compare the evolution of immigrant distributions across urban areas to derive whether immigrants' concentration increased or decreased over the study period in specific urban areas and regions in France. At the macro-geographical level, across urban areas, the most notable finding is the lower concentration of non-European immigrants living in public housing. Non-European immigrants in public housing are much more dispersed across urban areas than are those in private housing. On the other hand, one does not observe large differences in concentration between European immigrants in public and private housing.

I then examine the evolution of the distribution of immigrants within urban areas. I use census tracts to compute average neighborhood characteristics and various dissimilarity indices between groups. One of the problems with a longitudinal study of this kind is that the geographical definitions of census tracts and urban areas have changed dramatically over time, and these discrepancies might affect the results. To deal with this issue, I restrict the study to urban areas with more than 50,000 inhabitants (including municipalities within urban areas of all sizes). Because data on infra-city geographical areas in public use census files are either censored or not available in the 1982 and 1990 censuses, I focus on the 1968 and 1999 censuses. To obtain census tracts of a comparable size over time, I aggregate smaller census areas from 1968 to obtain areas with comparable population sizes to those reported in the 1999 census tracts. This implies that the changes reported in this study are not an artifact of changes in the boundaries of the basic geographical units used in the analysis.

The results of this paper indicate that segregation in France changed from 1968 to 1999 from a pattern of segregation by national origin to one of segregation by regional origin for those in public housing in which members of non-European groups increasingly live in the same neighborhoods. Since 1968, all indicators suggest that average segregation levels, particularly ethnic segregation of immigrants from the same country of origin, have declined, especially for European immigrants. For non-European immigrants participating in public 
housing, the decline in national segregation has been counterbalanced by an increase in the share of non-Europeans in the neighborhood, often from the same region of origin. I also find that most of the differences between European and non-European immigrants are not related to the different average arrival years between groups.

While segregation levels have decreased unambiguously for non-European immigrants in private housing, they have increased significantly for those in public housing. Dissimilarity indices computed between immigrant groups confirm the increase in the clustering in similar neighborhoods of non-European immigrant groups over the study period.

One limitation of these results is that, because of the limited data available, we cannot follow the evolution of segregation of second-generation immigrants; thus, we concentrate our study on first-generation immigrants. Given the large increase in non-European immigration in recent decades, these limitations are a major issue for research in ethnic segregation.

The next section provides a review of the literature on segregation, with a particular emphasis on France and Europe. The second section describes the data. Because of public housing's potential influence on segregation, the third section studies the large increase in immigrants' rate of participation in public housing during the 1980s and the 1990s. The fourth section discusses the different indices used to quantify segregation levels. The fifth section documents the change in immigrant concentration across urban areas, while the sixth section documents changes in immigrant segregation within urban areas. The last section concludes.

\section{Literature Review}

Following the approach of the Chicago School of sociology, there exists a large body of evidence on the recent and past trends of segregation in the US and Canada of income groups (Jargowsky, 1996; Massey and Fischer, 2003; Fong and Shibuya, 2000), blacks and whites (Wilson, 1987; Farley and Frey, 1994; Cutler, Glaeser and Vigdor, 1999), and ethnic minorities (Frey and Farley, 1996; Cutler, Glaeser and Vigdor, 2008). However, there is surprisingly little quantitative evidence of the trends of segregation for continental Europe, particularly for France (Musterd, 2005). Immigrant segregation in France and Europe is particularly interesting to study because, as I show in this paper, both the level and the mechanisms of segregation appear to differ in many aspects with respect to those observed in North America.

However, several pioneering studies on immigrant segregation in France were published during the writing of this paper. These papers focus on a more restrictive set of 
urban areas and use a larger geographical level within cities to construct segregation indices. These contributions are complementary with those of the present research given that each geographical level documents a different aspect of segregation (see, e.g., Safi (2009) for a discussion).

Safi (2009), using the same data utilized in this paper, provides one of the first systematic studies of the evolution of segregation in France between 1968 and 1999. Unlike the present research, she computes dissimilarity indices using municipalities instead of census tracts or urban areas. As she recognizes, municipality sizes within French agglomerations are very diverse, making her results difficult to interpret and strongly dependent on the variation of political divisions across urban areas. Moreover, she restricts her sample to include only the eight largest urban areas in France, while I use all urban areas with more than 50,000 inhabitants over the period, thereby including between 100 and 120 urban areas in the analysis. Because of these differences, the results of her work and of this paper are difficult to compare. However, her results are broadly consistent with mine: she also reports a large difference in segregation levels between European and non-European immigrants and a decrease in dissimilarity indices across most groups over the period.

Prétéceille (2009) studies the evolution of ethno-racial segregation between 1982 and 1999 in the Paris urban area. His study uses both Parisian quartiers (each with about 5,000 inhabitants) and municipalities around Paris to compute dissimilarity indices. The dissimilarity indices that he reports for the Paris urban area are slightly lower than the value I obtain using census tracts. ${ }^{1}$ Unreported results suggest that segregation levels for nonEuropean immigrants in Paris are much lower than in most other French cities. These differences might explain why the average dissimilarity indices reported in this study are higher than that observed by Prétéceille (2009).

Other aspects of segregation have increasingly been explored. Segregation is likely to be less of a problem if it is temporary and there is a lot of mobility between segregated and less segregated places. In a recent work, Pan Ké Shon (2010), using panel data, studies the mobility of immigrants between 1990 and 1999. His results indicate nonnegligible mobility of immigrants from distressed neighborhoods over time. However, he finds that non-European immigrants, particularly Africans, are more likely to stay in disadvantaged neighborhoods than non-Africans.

\footnotetext{
${ }^{1}$ For example, for the Paris urban area, I obtain dissimilarity indices of, respectively, 0.38 and 0.28 for Moroccans and Portuguese, while Prétéceille reports indices of 0.33 and 0.19 for these groups.
} 
The relation between income and segregation has also been documented, but without systematically studying the role of public housing as is done in this paper. One original study by Maurin (2004) documents changes in social class and income segregation across neighborhoods including from 20 to 30 closest neighbors. Prétéceille (2003) investigates segregation with respect to socio-professional status and unemployment in the Paris urban area.

For Europe, the impact of public housing on segregation has already been emphasized by Musterd and Deurloo (1997) for the Netherlands: as in this paper, they report moderate to average levels of segregation and underline how public housing seems to increase the clustering of non-European immigrant groups in the same neighborhoods. They report, for example, that the patterns of concentration of Turks and Moroccans in Amsterdam are very similar. These results closely match what we observe in France for non-European immigrants.

For the UK, Peach (1996) reports dissimilarity indices between ethnic groups for the Greater London area in 1991 at the Ward level (about 10,000 inhabitants). His figures are typically much higher than those observed for France and reported in this paper or in Prétéceille (2009) or Safi (2009). Most of the dissimilarity indices Peach calculates for what he classified as visible ethnic groups are greater than 0.5 . However, recent research by Peach (2009) documents a decrease in segregation in the UK between 1991 and 2005. 


\section{The Data}

The empirical analysis draws data from the 1968, 1975, 1982, 1990 and 1999 Census. The sampling rate for the individual files is particularly large, at $25 \% .^{2}$ This enables me to study small subpopulations such as immigrants at a relatively detailed geographical level without worrying too much about sampling errors, which often plague empirical work on immigration (Aydemir and Borjas, 2006). An immigrant is defined as a foreign-born individual who is a non-citizen or a naturalized French citizen. The national origin of immigrants is determined using their country of birth.

Segregation indices are sensitive to differences in the geographical boundaries used to compute them, such as the number of individuals included at the basic geographical level used for the computation (Massey et Denton, 1988). I try to construct comparable measures of segregation over time that are relatively unaffected by changes in geographical definitions. To the greatest extent possible, I control for the impact of changes in geographical boundaries over time and across cities by using geographical definitions of urban areas that remain constant over time and by using census tracts of similar sizes.

The largest geographical boundary used in this study is urban areas. Urban areas are aggregations of municipalities between which there are no discontinuities across constructions and are thus redefined by the French statistical institute (INSEE) during each census. ${ }^{3}$ To keep the data comparable over time and across cities dissimilarity indices, I focus on urban areas of more than 50,000 inhabitants each year (but include municipalities of all sizes within these urban areas). ${ }^{4}$ By excluding small urban areas, I focus on the segregation of the large majority of immigrants, so the results are not driven by high segregation figures in small urban areas with few immigrants. These urban areas included $57.6 \%$ and $78.8 \%$ of European and non-European immigrants, respectively, in 1968 (63\% of all immigrants). In 1999, they included $62 \%$ and $82 \%$ of European and non-European immigrants, respectively $(72 \%$ of all immigrants). One interesting characteristic of the French statistical system is that each municipality has had a unique administrative identifier since 1945, which enables similar urban areas to be matched over time. Municipalities included in urban areas are matched over

\footnotetext{
${ }^{2}$ Except in 1975 , in which it is $20 \%$.

${ }^{3}$ Urban areas typically aggregate many different municipalities. For example, the urban area of Paris in 1999 is composed of 396 municipalities, whereas the urban area of Toulouse is composed of 72 municipalities.

${ }^{4}$ Municipalities of all sizes are included in the sample given that urban areas are composed of many small municipalities. The size restriction applies to urban areas, not municipalities.
} 
time and aggregated into similar urban areas using the 1999 urban area definitions. This precaution excludes the possibility that results could be driven by a change in the boundaries of urban areas over time, a problem that is encountered in the US Census and in longitudinal studies more generally.

To compute segregation indices at the city level, I use census tracts (each with about 2,500 inhabitants). Census tracts of similar sizes across cities were first made accessible to researchers in 1999 and, for confidentiality reasons, are not available across all years. ${ }^{5}$ In particular, there is no information available on a geographical-level equivalent to or smaller than a census tract in the 1982 and 1990 Census. Alternative geographical boundaries available in these two years are not consistently defined across municipalities, and their sizes vary widely across locations. Therefore, to compare the evolution of segregation at the census-tract level, I restrict the study to the years 1968 and 1999.

There is large variance in the sizes of the equivalent of census tracts (îlots) available in the 1968 census. These discrepancies in the number of individuals in the basic geographical areas might affect the comparisons of the results between 1968 and 1999. I use information on census blocks to create census tracts of equivalent size to the ones available in 1999. Contiguous census blocks in 1968 have been aggregated or disaggregated to create census tracts of approximately the same size as census tracts in 1999. I eliminate isolated and unmatched census tracts, which represent $1.7 \%$ of the population. Details of this procedure are available upon request. As a result, census tracts from both censuses used in the analysis have comparable sizes and distributions. ${ }^{6}$

To compare the results with studies on segregation using US census data, it should be noted that the average size of a French census tract is approximately half the size of a US census tract. If anything, the smaller census tract size of the French census should, therefore, overstate the segregation levels in France with respect to the US.

\footnotetext{
${ }^{5}$ In the French 1999 census, census tracts are called IRIS 2000. See Lipatz (2006) for a concise presentation of their characteristics. I restrict the study to "population" census tracts (IRIS d'habitation) and exclude business or commercials census tracts (IRIS d'activité), which mostly consist of sparsely populated industrial or commercial areas. These census tracts include less than $0.71 \%$ of the population.

${ }^{6}$ The median and the mean population of a census tract in 1999 (1968) are, respectively, 2,488 (2,496) and 2,624 (2,703). There are 12,400 census tracts in 1999 and 8,599 in 1968.
} 


\section{Immigration and Public Housing in France}

The public housing supply in France increased dramatically during the 1960s and 1970s. Public housing relocated individuals residing in cities to neighborhoods where housing projects were located and thus is likely to have influenced the evolution of segregation since 1968. Its influence on non-European immigrants is potentially particularly large as rates of participation in public housing by these groups increased tremendously during the period under study, as I show below.

The year 1968 is an interesting benchmark as the stock of public housing units was considerably lower at that time. Unlike today, the participation rate of immigrants in public housing was probably negligible, as their access was severely restricted before the 1970s. Pinçon (1976) has shown that in 1968, only 5.5\% of foreign workers in the Paris urban area lived in public housing versus $15.3 \%$ of natives. $^{7}$

Originally, public housing constructions were unrelated to immigrants' needs, which explains immigrants' relatively lower participation rates in public housing during the 1960s and 1970s. Until the 1970s, housing policies for immigrants targeted single male migrants by providing housing in collective dormitories called "foyer Sonacotra" (Weil 2005, p. 51), making family reunification impossible. Until the middle of the 1970s, the national authorities considered the immigration of Africans and Maghrebis to be temporary, and the government explicitly tried to discourage reunification of these immigrants' families. Therefore, immigrants' access to housing projects was severely restricted. ${ }^{8}$ As a result, many immigrants lived in slums on the outskirts of French urban areas. ${ }^{9}$ After 1970, the government decided to eliminate immigrant slums, and the access of immigrants to public housing was progressively unrestricted during the 1970s as family reunification immigration became easier (Weil 2005, p. 55).

\footnotetext{
${ }^{7}$ Schor (1996, p. 214) reports that there existed quotas in the 1960 s which limited the number of immigrants per projects to 5\%. Moreover, immigrants must have been residents in France for 10 years before being eligible. Weil (2005, p.52) indicates that the access of immigrants to public housing was partially allowed by the government only after 1970, whereas, in the first studies of public housing inhabitants, such as Durif and Marchand (1975), the word "immigrant" is never mentioned.

${ }^{8}$ See, e.g., Stebe (2007) for a concise presentation of the history of public housing in France. ${ }^{9}$ Lequin (2006, p.410) reports there were 113 slums in the Paris region in 1970. The biggest was 'La Folie' in Nanterre where 23,000 individuals lived, mostly immigrants from Algeria. See also Schor (1996, p.214).
} 
Table 1 documents the increase in non-European immigrants' rates of participation in public housing since $1982^{10}$ by reporting the participation rates of immigrant and native households. ${ }^{11}$ During this period, the difference between the participation rate of natives and that of non-European immigrants increased dramatically. While the participation rates of natives or immigrants from Europe increased by one percentage point at most over the study period, participation rates of non-European immigrants increased by between 10 and 15 percentage points for nationalities from the Maghreb and Africa between 1982 and 1999. As a result, in 1999, there was a 28-percentage-point gap between the participation rates of Maghrebis and natives.

The differences in participation rates across immigrant groups in 1999 are striking, particularly between Europeans (19.7 percent) and non-Europeans. Among non-Europeans, Maghrebis (47.9 percent) and Africans (43.5 percent) have the highest participation rates. The average participation rate of immigrants from Asia is the lowest among non-Europeans but varies widely across groups: the participation rate of immigrants from Turkey is $46.4 \%$ and is thus comparable to the participation rate of Africans and Maghrebis.

\footnotetext{
${ }^{10}$ There is no data on public housing participation in the 1968 and in 1975 censuses, and to my knowledge, there is no alternative source available to study the participation rates of immigrants before 1982. The "housing conditions surveys" (Enquêtes Logement) of 1973 and 1978 collected by the French statistical institute did collect information on public housing participation but do not contain information on nationality.

${ }^{11}$ A household is classified as an immigrant household if the head of household is an immigrant.
} 
Table 1 : Proportion of Immigrant Households Living in Public Housing 1982-1999

\begin{tabular}{|c|c|c|c|c|c|}
\hline Participation Rates & 1982 & 1990 & 1999 & \multirow{2}{*}{\multicolumn{2}{|c|}{$\begin{array}{c}\text { Linear Regression Adjusted } \\
\text { Participation Rates } \\
\text { (with respect to natives) }\end{array}$}} \\
\hline Immigrants & 23.7 & 27.3 & 32.8 & & \\
\hline Natives & 17.9 & 18.7 & 19.7 & & $\begin{array}{c}\text { Includes } \\
\text { Municipalities }\end{array}$ \\
\hline Europe & 18.1 & 19.3 & 19.7 & & Fixed Effect \\
\hline Spain & 22.0 & 22.8 & 22.8 & 1.6 & 5.3 \\
\hline Portugal & 25.2 & 26.6 & 25.1 & -4.1 & -5.9 \\
\hline Italy & 14.2 & 14.4 & 14.5 & -6.1 & -4.2 \\
\hline Africa & 26.4 & 32.3 & 43.5 & & \\
\hline Maghreb & 34.2 & 42.6 & 47.9 & & \\
\hline Algeria & 35.2 & 43.4 & 50.4 & 26.4 & 21.4 \\
\hline Morocco & 37.6 & 42.8 & 49.2 & 24.4 & 20.4 \\
\hline Tunisia & 27.3 & 37.8 & 39.1 & 15.9 & 13.6 \\
\hline Asia & 25.9 & 27.1 & 31.7 & & \\
\hline Turkey & 31.2 & 31.4 & 46.4 & 17.6 & 13.1 \\
\hline Vietnam & 29.4 & 32.1 & 32.0 & 12.5 & 7.3 \\
\hline Other nationalities & 17.3 & 19.6 & 20.1 & & \\
\hline
\end{tabular}

Notes: The first three columns of the table report public housing participation rates of immigrant households in 1982, 1990 and 1999. A household is defined as an immigrant household if the head of household is immigrant. Regions of origins are defined using the head of household's country of birth. The last two columns report OLS estimates of country-fixed effects of the probability of living in public housing for a given household in 1999. The model includes controls for education, five dummies for age, whether the individual is living in a couple with children, interactions between education and age and interactions between education and living in a couple with children. The model reported in the last column includes municipality-fixed effects for 3,518 municipalities. The number of observations is 4,705,554 in both regressions. All parameters are significant at the one percent level with robust standard errors.

Sources: 1982, 1990 and 1999 censuses. 
To understand how public housing affects segregation, it is important to know whether these large differences in participation rates between immigrant groups and between immigrants and natives are due simply to differences in household characteristics or to a special appeal of public housing to immigrants due to other factors. Public housing apartments were specifically built for large families and are more prevalent in some urban areas. Immigrant households might have different characteristics and distributions across cities than native households, which could explain these variations across groups.

To account for these differences, I decompose the gap in participation rates across immigrant groups and natives between a part explained by differences in household characteristics across groups and an unexplained part specific for each national group. To do this, I estimate a linear probability model where the outcome variable is the probability of living in public housing in 1999 for the household, including controls for the effect of observable differences on the probability of participating. Individual covariates included in the regression are flexible controls for four education groups; five dummies for age; being part of a couple with children; and interactions between education and both of the latter covariates. Country of origin fixed effects for immigrant groups are included in the regression and reported in the table to indicate differences in participation rates with respect to natives, which remained unexplained by differences in observable characteristics included in the model. Results are presented in the final two columns of Table 1. Even after accounting for observable differences, the figures still differ greatly between European and non-European groups. The figures indicate that, conditional on their observable characteristics, immigrants from Italy or Portugal actually have lower participation rates than natives with similar characteristics. For non-European immigrant groups, country fixed effects are positive and much larger. On the whole, differences in observable characteristics between natives and immigrants explain less than 3 percentage points of the gap of 30 percentage points between the participation rates of Algerians or Moroccans and that of natives.

One other reason for these differences could be that immigrants live in municipalities in which the public housing supply is large and therefore both natives and immigrants living in these municipalities are more likely to live in public housing. Because there is a large disparity in the public housing supply across municipalities, differences in participation rates may simply reflect differences in location across municipalities. To derive how much of the differences in participation rates can be explained by differences in location across urban areas, the last column of Table 1 reports regression results including fixed effects for each of the 3,518 municipalities included in the sample. Controlling for municipality fixed effects 
typically decreases country fixed effects by 16 to $19 \%$ for most groups; that is, by between 3 and 5 percentage points. This suggests that only a small part of the gap may be accounted for by the fact that these immigrants live in municipalities in which the participation rates of both natives and immigrants are higher. Even when the differences in the participation rates of inhabitants across municipalities are taken into account, the effect on the participation rate of being a member of a non-European immigrant group remains particularly large.

From these results, I conclude that only one third of the 30-percentage-point gap in participation rates between non-European immigrants and natives can be explained by differences in observable characteristics across households, such as family size, socioeconomic status or location choice. Differences in rates of participation in public housing are thus particularly large for non-European immigrants, even after controlling for observable characteristics or urban area fixed effects.

\section{Measurement Issues in Spatial Segregation}

Spatial segregation has many aspects and can therefore be measured in different ways (Massey and Denton, 1988; Echenique and Fryer, 2007). Because a plurality of indicators is preferred to document the different aspects of segregation, I use several alternative indices and statistics computed at different geographical levels. In this section, I present and discuss the interest and limitations of the indices chosen in this paper.

To approximate the level of segregation within and across national groups, the most straightforward measure of ethnic concentration is the set of average characteristics of neighborhoods. Average neighborhood characteristics are a simple and intuitive indicator of segregation and can be calculated using different variables. They reflect the degree to which the average characteristics of a neighborhood differ from the case in which immigrants are randomly allocated across the population. I compute the average shares of immigrants from the same and from different national groups in the neighborhood (Borjas, 1995) to document the evolution of segregation of immigrants within and across groups.

However, the average characteristics of census tracts are not suitable for documenting other aspects of spatial segregation. Among other reasons, the average characteristics of neighborhoods do not capture well the different distributions of two groups among neighborhoods in an urban area. ${ }^{12}$ Several alternative measures of spatial segregation have

\footnotetext{
${ }^{12}$ For example, suppose that there are two urban areas in which each census tract has the same size: in the first urban area, immigrants are spread evenly across tracts and make up $10 \%$ of the population in each tract, while in the second urban area, immigrants are all
} 
been proposed in the literature, but the most popular is the dissimilarity index. The dissimilarity index provides results that are directly comparable with other studies and has an intuitive interpretation. Formally, the dissimilarity index for a particular subgroup of the population can be defined as

$$
D_{i}=\frac{1}{2} \sum_{k}\left|\frac{G_{k}}{G_{\text {total }}}-\frac{N_{k}}{N_{\text {total }}}\right|,
$$

where $k$ is an index indicating the relevant spatial unit dividing the population of interest; $G_{k}\left(N_{k}\right)$ is the total number of individuals (not) from group $k$ in area $k$; and $G_{\text {total }}\left(N_{\text {total }}\right)$ is the total number of individuals (not) from group $k$ in the population. A common interpretation of the dissimilarity index is that it represents the share of group members (or non-group members) who would have to switch neighborhoods to achieve an even distribution across the geographical units. The dissimilarity index is thus equal to zero when two groups are evenly distributed across geographic units and is equal to one when no member of the group shares a unit in common with those outside the group.

\section{Macro-Level Segregation}

As in other countries, immigrants tend to be concentrated in specific regions and urban areas, such as Paris, Marseille and Lyon (Desplanques and Tabard, 1991; Desplanques, 1996). This section documents how the distribution of immigrants across urban areas changed over time and studies whether immigrants tend to "spread" across cities or whether they cluster in a small group of cities. The evolution of the distribution of immigrants across cities will directly influence whether immigrants represent a large share of the urban population.

Following Massey and Fischer (2003), we report how the concentration of immigrants changed between 1968 and 1999 by computing dissimilarity indices using urban areas with more than 50000 inhabitants as the basic geographic unit. ${ }^{13}$ Table 2 reports the evolution of dissimilarity indices across groups of immigrants.

concentrated in one tract and still make up $10 \%$ of the population of this tract. The number of immigrants within tracts for the average immigrant is thus $10 \%$ in both urban areas even if, in one urban area, immigrants are all concentrated in the same tract. The dissimilarity index that I present below accounts for these differences. It is equal to 0 in the first urban area and is strictly superior to $1 / 2$ in the second case.

${ }^{13}$ I have tested the robustness of the results to the choice of the geographical unit used to construct the dissimilarity indexes. Dissimilarity indexes using regions (22 units), matched urban areas of different size (95 and 23 units) and unmatched urban areas have also been 
In general, we observe higher levels of segregation at the macro levels for nonEuropean immigrants, but the trends differ across groups and regions of origin. While segregation levels increased slightly for immigrants from Europe during the 1990s, the concentration of Maghrebis across urban areas decreased from 0.267 to 0.192 between 1968 and 1990. Looking across national groups reveals notable differences within regional groups for some nationalities. Across Maghrebis, the indices decreased from 0.276 to 0.230 for Algerians and, quite similarly, from 0.274 to 0.201 for Moroccans. The evolution of Tunisians' concentration is unique because this group has much higher concentration indices that do not change much over the period. For Africans, concentration levels increased during the 1970s, from 0.243 in 1968 to 0.325 in 1982, and remained roughly constant thereafter. For Asians, after a period of decrease during the 1970s and 1980s in which the dissimilarity index fell from 0.325 in 1968 to 0.257 in 1982, the concentration indices increased during the 1990s to reach 0.297 in 1999. The dissimilarity indices of Portuguese (0.30) and Tunisian (0.36) immigrants stay roughly constant over the period.

calculated. Results are broadly similar to the one presented here and are available upon request. 
Table 2 : Macro-Segregation across Urban Areas with more than 50000 inhabitants

\begin{tabular}{|c|c|c|c|c|c|}
\hline Year & 1968 & 1975 & 1982 & 1990 & 1999 \\
\hline Africa & 0.281 & 0.341 & 0.354 & 0.341 & 0.351 \\
\hline Public Housing & & & 0.328 & 0.311 & 0.357 \\
\hline Private Housing & & & 0.372 & 0.370 & 0.370 \\
\hline Asia & 0.361 & 0.312 & 0.272 & 0.292 & 0.310 \\
\hline Public Housing & & & 0.232 & 0.227 & 0.259 \\
\hline Private Housing & & & 0.337 & 0.352 & 0.361 \\
\hline Europe & 0.169 & 0.171 & 0.175 & 0.184 & 0.199 \\
\hline Public Housing & & & 0.172 & 0.186 & 0.200 \\
\hline Private Housing & & & 0.194 & 0.196 & 0.207 \\
\hline Portugal & 0.356 & 0.310 & 0.309 & 0.307 & 0.317 \\
\hline Public Housing & & & 0.290 & 0.299 & 0.309 \\
\hline Private Housing & & & 0.329 & 0.322 & 0.325 \\
\hline Maghreb & 0.267 & 0.219 & 0.204 & 0.194 & 0.192 \\
\hline Public Housing & & & 0.167 & 0.161 & 0.176 \\
\hline Private Housing & & & 0.254 & 0.256 & 0.245 \\
\hline Algeria & 0.276 & 0.230 & 0.233 & 0.230 & 0.228 \\
\hline Public Housing & & & 0.214 & 0.218 & 0.225 \\
\hline Private Housing & & & 0.258 & 0.258 & 0.244 \\
\hline Morocco & 0.274 & 0.198 & 0.181 & 0.186 & 0.201 \\
\hline Public Housing & & & 0.258 & 0.205 & 0.213 \\
\hline Private Housing & & & 0.233 & 0.244 & 0.247 \\
\hline Tunisia & 0.398 & 0.370 & 0.362 & 0.359 & 0.355 \\
\hline Public Housing & & & 0.287 & 0.284 & 0.307 \\
\hline Private Housing & & & 0.400 & 0.403 & 0.394 \\
\hline
\end{tabular}

Notes: The table reports dissimilarity indexes across matched urban areas of more 50000 inhabitants for several immigrant groups. For each group, dissimilarity indexes for public housing participants and immigrants in private housing are reported after 1982, respectively, in the lines Public Housing and Private Housing. Sources: 1968, 1975, 1982 and 1999 censuses. 
The most striking result from Table 2 is the large difference in concentration between public housing participants and immigrants living in private housing for non-European immigrant groups across urban areas. The table reports different dissimilarity indices for these two groups after 1982. The results indicate, if anything, a much lower concentration of immigrants in public housing across urban areas. For Maghrebis, the dissimilarity index for immigrants in public housing is eight percentage points lower than for immigrants in private housing ( 0.167 versus 0.254$)$ in 1982 . Throughout the period, the degree of observed segregation is much greater among private housing inhabitants than among public housing inhabitants. For immigrants from Asia, there is a difference in the dissimilarity index of 10 percentage points between immigrants in private housing and those in public housing $(0.232$ versus 0.337 in 1982). For Portuguese immigrants and European immigrants in general, differences in segregation levels between immigrants in public and private housing are much lower, particularly in the most recent period.

On the whole, the segregation of immigrants across urban areas has decreased over time, particularly for public housing inhabitants. The results indicate that the distributions of non-European immigrants in public and private housing differ strongly across urban areas. Non-European immigrants in public housing are less concentrated across urban areas than are immigrants in private housing.

\section{Neighborhood-level Segregation}

As we emphasized in the previous section, during the period under study, the participation rates of non-European immigrants increased, and the geographical concentration of immigrants across urban areas was much lower for public housing participants. In this section, I investigate how these two phenomena are related to the evolution of the segregation of immigrants within cities. I compare dissimilarity indices and average neighborhood characteristics across groups and urban areas between 1968 and 1999. Given that neighborhood characteristics might differ and that public housing participation is likely to influence immigrants' location within cities, for 1999, I report different segregation indices for immigrants living in public and private housing.

\subsection{Average Neighborhood Characteristics}

Table 3 reports the characteristics of neighborhoods for the average immigrant in 1968 and 1999 across regional and national origins. Within each panel, the first column indicates 
the share of the group in the French population, while the second column reports the group's participation rate in public housing in 1999.

To account for a potential relationship between public housing participation and average segregation levels, neighborhoods' characteristics are reported separately for immigrants in public and private housing in 1999. The first four rows report neighborhood characteristics defining immigrant groups using geographical areas, while other rows report these characteristics for the most common nationalities of immigrants in 1999. If immigrants were randomly allocated across tracts, the share of immigrants per tract would be equal to $10.1 \%$ in 1999 and $8.6 \%$ in 1968 , or immigrants' actual share of the total population.

However, the average immigrant in public housing lived in census tracts with about $18 \%$ immigrants in 1999, while the immigrant share in 1968 is $14 \%$. 
Table 3 : Average Neighborhood Characteristics in 1968 and 1999 (Urban Areas with more than 50,000 inhabitants)

\begin{tabular}{|c|c|c|c|c|c|c|c|c|c|}
\hline National Origins & $\begin{array}{r}\% \text { of } \\
\text { population in } \\
\text { group } 1999\end{array}$ & $\begin{array}{r}\text { Share living } \\
\text { in public } \\
\text { housing in } \\
1999\end{array}$ & $\begin{array}{r}\text { Public Hou } \\
\% \text { of } \\
\text { population in } \\
\text { tract } \\
\text { immigrant }\end{array}$ & $\begin{array}{l}\text { sing } 1999 \\
\% \text { population } \\
\text { same national } \\
\text { origin }\end{array}$ & $\begin{array}{r}\text { Private Ho } \\
\% \text { of } \\
\text { population in } \\
\text { tract } \\
\text { immigrant }\end{array}$ & $\begin{array}{l}\text { sing } 1999 \\
\% \text { population } \\
\text { same national } \\
\text { origin }\end{array}$ & $\begin{array}{r}\text { All hous } \\
\% \text { of } \\
\text { population in } \\
\text { group in } 1968\end{array}$ & $\begin{array}{r}1968 \% \text { of } \\
\text { population in } \\
\text { tract } \\
\text { immigrant }\end{array}$ & $\begin{array}{r}\% \text { population } \\
\text { same national } \\
\text { origin }\end{array}$ \\
\hline All Immigrants & $10.12 \%$ & $32.8 \%$ & $18.2 \%$ & $18.2 \%$ & $14.6 \%$ & $14.6 \%$ & $8.63 \%$ & $14.1 \%$ & $14.1 \%$ \\
\hline Non-Europeans & 6.24 & 43.1 & 19.1 & 15.3 & 16.7 & 11.7 & 2.71 & 16.1 & 8.5 \\
\hline Europe & 3.88 & 19.7 & 15.3 & 4.8 & 12.3 & 5.9 & 5.92 & 13.1 & 9.7 \\
\hline Asia & 1.50 & 31.7 & 20.0 & 5.0 & 17.8 & 5.3 & 0.42 & 12.7 & 2.2 \\
\hline Africa & 1.08 & 43.5 & 19.5 & 4.0 & 17.2 & 3.0 & 0.31 & 15.0 & 3.1 \\
\hline Maghreb & 3.33 & 47.9 & 18.7 & 9.2 & 16.3 & 6.8 & 1.85 & 17.3 & 8.1 \\
\hline \multicolumn{10}{|l|}{ Maghreb } \\
\hline Algeria & 1.52 & 50.4 & 18.3 & 4.7 & 15.9 & 3.5 & 1.09 & 18.7 & 9.2 \\
\hline Morocco & 1.24 & 49.2 & 19.1 & 5.2 & 16.6 & 3.9 & 0.34 & 16.4 & 7.8 \\
\hline Tunisia & 0.57 & 39.1 & 18.7 & 2.3 & 16.6 & 2.1 & 0.42 & 14.3 & 5.4 \\
\hline \multicolumn{10}{|l|}{ Europe } \\
\hline Italy & 0.77 & 14.5 & 14.7 & 1.9 & 11.5 & 2.3 & 1.94 & 13.9 & 10.3 \\
\hline Spain & 0.58 & 22.8 & 15.0 & 1.3 & 11.3 & 1.6 & 1.49 & 12.8 & 9.3 \\
\hline Portugal & 1.28 & 25.1 & 15.9 & 2.7 & 13.1 & 3.1 & 0.66 & 14.9 & 11.1 \\
\hline
\end{tabular}

Notes: The first column reports the size of the population of the group, while the second column reports public housing participation rates in

1999. Other columns report average census tract characteristics in 1968 and in 1999. The percentage of the population in tract immigrant is the average share of immigrants in the census tract, while the percentage of population same ethnicity is the average share of immigrants from the same country or region of origin. Sources: 1968 and 1999 censuses 
Looking at the average immigrant share per group of immigrants, the figures indicate a large dispersion across groups of immigrants, particularly between European and nonEuropean immigrants. On the whole, European immigrants in both years lived in neighborhoods with fewer immigrants than did non-European immigrants, particularly for those in private housing in 1999. In this year, most variations in average immigrant share resulted from differences between public housing participants and others. Differences in neighborhood characteristics between public and private housing participants are large, confirming that public housing inhabitants live in neighborhoods with different average characteristics from the neighborhoods of inhabitants of private housing. Immigrants from Asia, Maghreb and Africa in public housing lived in tracts of about 19-20\% immigrants, versus $16-17 \%$ for similar immigrants in private housing. For immigrants as a whole, the average immigrant share is higher by four percentage points in public housing relative to private housing (18\% vs. 14\%). Moreover, across national groups living in public housing, we also observe variations in neighborhood characteristics, indicating that European immigrants in public housing live in neighborhoods with fewer immigrants. In practice, there are large differences in average neighborhood characteristics between groups. This suggests that the distribution of immigrants from different groups across housing projects tend to differ, and European immigrants live in housing projects with fewer immigrants on average.

Turning now to the share of immigrants from the same national group in the neighborhood, the differences across groups are larger. For immigrants from Southern Europe, the decrease in national concentration in 1999 with respect to 1968 is particularly large. In 1968, although Italian, Spanish and Portuguese immigrants each made up less than $2 \%$ of the French population in 1968, the typical immigrant from these countries lived in census tracts in which his or her own group made up about $10 \%$ of the population, which is one of the highest values across all nationalities and regional groups. However, in 1999, immigrants from Southern Europe had the lowest level of segregation across all groups and lived in tracts with less than $2 \%$ immigrants of the same nationality. This figure is broadly similar for immigrants in public and in private housing. For all groups of immigrants in private housing in 1999, the figures indicate a very low share of the population from the same national group compared with the figures for 1968.

For non-European immigrants, segregation by national origin decreased across all groups between 1968 and 1999. Immigrants from Algeria and Morocco lived in tracts with between $8 \%$ and $9 \%$ of immigrants from the same country of origin in 1968 , while the shares 
of similar immigrants for these two groups were only 5\% for public housing participants and between $3 \%$ and $4 \%$ for private housing in 1999. Simultaneously, the segregation of nonEuropean immigrants per region of origin increased: in 1999, immigrants from Maghreb lived in census tracts with 9.2\% immigrants from Maghreb versus 8.2\% in 1968. Similarly, the average non-European immigrant lived in tracts in which non-European immigrants made up $8.5 \%$ of the population in 1968 , but this value was $15.3 \%$ for those in public housing in 1999 .

This evidence suggests that, between 1968 and 1999, while the level of segregation by country of origin decreased for most groups of immigrants, even for immigrants living in public housing in 1999, the segregation by region of origin of non-European immigrants increased for participants in public housing. When ethnicity is measured using region of origin instead of country of origin, non-European immigrants in public housing in 1999 lived in tracts with above-average segregation levels relative to private housing and with a higher density of individuals of the same national origin relative to 1968. For immigrants in public housing, segregation levels in 1999 were higher than in 1968 with respect to the share of immigrants from all origins, while the share of immigrants of their own ethnicity in the neighborhood declined. Therefore, immigrants in public housing in 1999 lived in neighborhoods that were more ethnically diverse than those in which similar immigrants lived in 1968.

As emphasized informally by other authors (e.g., Wacquant, 2007), compared with the US, these average segregation levels are relatively moderate. As a comparison, Borjas (1995) reports that, in 1970, the average Cuban or Mexican immigrant lived in a tract in which his or her own group made up about $22 \%$ of the population, while these groups' shares of the total population were $1.3 \%$ for Mexicans and $0.3 \%$ for Cubans. These results confirm not only that the contemporary levels of segregation appear to be lower, but also that mechanisms of segregation differ. ${ }^{14}$

\subsection{Neighborhood Characteristics and Length of Stay in France}

To explain the large differences across groups of immigrants, it is interesting to determine whether these differences reflect different average arrival times across groups. Immigrants might "assimilate" over time (Chiswick, 1978); for example, they become more fluent in French and more familiar with the French culture. As emphasized by Pan Ké Shon

\footnotetext{
${ }^{14}$ See Peach (1999), who describes the differences between US and UK models and mechanisms of segregation.
} 
(2010), residential mobility in disadvantaged neighborhoods in France is relatively high. Therefore, immigrants may move to less segregated neighborhoods after an initial period in which they live in close contact with members of their group. The differences in segregation levels observed in the previous section might thus be explained by different average arrival dates across groups of immigrants. Because many European immigrants arrived in France earlier on average than non-European immigrants, they thus had more time to assimilate. The assimilation theory would explain why I observe lower levels of national segregation for European immigrants in 1999 because many of them, particularly immigrants from Spain or Italy, were part of an earlier wave of immigration.

Because immigration from Asia and Africa is relatively recent in France and very few immigrants from these areas entered France during the 1960s and 1970s, I compare neighborhood characteristics using only cohorts of immigrants from Europe and Maghreb.

Table 4 reports the characteristics of the census tract of the average immigrant relative to her decade of entry into France in 1999. The figures suggest that segregation decreased only mildly with time after arrival for immigrants living in private housing; the average immigrant share is $18 \%$ for immigrants from the Maghreb who arrived during the 1990s, while it is $15 \%$ for those who arrived during the 1960s. However, no comparable variation is observed for public housing participants; the average share of immigrants is $18.9 \%$ for those who arrived during the 1990s and $18.3 \%$ for those who arrived in the 1960s. A rapid comparison of segregation levels between European and Maghrebi immigrants indicates that immigrants from Europe who arrived during the 1990s and lived in private housing lived in tracts where $13.6 \%$ of the population was comprised of immigrants, while the same figure for Maghrebis is $18.0 \%$. Across cohorts, segregation levels are always higher for Maghrebis than for Europeans, with Maghrebis living in neighborhoods in which the immigrant share is higher by between 3 to 4 percentage points. Public housing participation rates across cohorts are remarkably similar for Maghrebis, while they tend to be higher for cohorts of European immigrants who entered in France during the 1960s and the 1970s.

This suggests that segregation levels do not decline much with the length of stay in France for those living in public housing. We observe that more of the variation in average segregation levels comes from specific group differences than from differences in arrival year. 
Table 4: Average Neighborhood Characteristics per Arrival Year in 1999 (Urban Areas with more than 50,000 inhabitants)

\begin{tabular}{|c|c|c|c|c|c|c|}
\hline & \multirow[b]{2}{*}{$\begin{array}{r}\text { Percentage } \\
\text { of } \\
\text { population } \\
\text { in group }\end{array}$} & \multirow[b]{2}{*}{$\begin{array}{r}\text { Share } \\
\text { living in } \\
\text { public } \\
\text { housing }\end{array}$} & \multicolumn{2}{|c|}{ Public Housing } & \multicolumn{2}{|c|}{ Private Housing } \\
\hline & & & $\begin{array}{r}\% \text { of } \\
\text { population } \\
\text { in tract } \\
\text { immigrant }\end{array}$ & $\begin{array}{r}\% \\
\text { population } \\
\text { same } \\
\text { ethnicity }\end{array}$ & $\begin{array}{r}\% \text { of } \\
\text { population } \\
\text { in tract } \\
\text { immigrant }\end{array}$ & $\begin{array}{r}\% \\
\text { populatio } \\
\text { n same } \\
\text { ethnicity }\end{array}$ \\
\hline Europe & & & & & & \\
\hline Entry 90-99 & $0.49 \%$ & $15.1 \%$ & $16.1 \%$ & $4.8 \%$ & $13.6 \%$ & $6.4 \%$ \\
\hline $80-90$ & 0.35 & 20.5 & 16.3 & 4.7 & 13.4 & 6.1 \\
\hline $70-80$ & 0.52 & 23.5 & 15.8 & 4.8 & 13.1 & 6.0 \\
\hline $60-70$ & 0.89 & 22.8 & 15.8 & 4.9 & 12.4 & 5.8 \\
\hline Maghreb & & & & & & \\
\hline Entry 90-99 & 0.40 & 47.7 & 18.9 & 9.3 & 18.0 & 7.8 \\
\hline $80-90$ & 0.60 & 52.7 & 19.4 & 9.7 & 17.8 & 7.7 \\
\hline $70-80$ & 0.75 & 55.3 & 18.9 & 9.2 & 16.5 & 6.8 \\
\hline $60-70$ & 0.60 & 47.1 & 18.3 & 9.0 & 15.0 & 5.9 \\
\hline
\end{tabular}

Sources and Notes: 1999 census data. The table reports average census tract characteristics across groups of immigrants who entered into France during a different decade. 


\subsection{Tract Level Dissimilarity Indexes 1968-1999}

Dissimilarity indices at the census tract level indicate the degree of spatial segregation of a group across neighborhoods with respect to the rest of the population. Following Frey and Farley (1994), unless otherwise indicated, I report the segregation of each minority group in relation to the rest of the population. Such indices indicate the absolute segregation of each group with respect to the whole population, not just natives.

In both years, the index is calculated using 114 matched urban areas with more than 50,000 inhabitants in $1999 .{ }^{15}$ Segregation indices for each group are computed using the weighted-average dissimilarity indices for these urban areas. As emphasized before, dissimilarity indices are sensitive to the number of individuals used to compute them. When there are few individuals from a group in a city, segregation indices can be high even if the distribution of individuals across sectors is random (Massey et Denton, 1988). Therefore, high dissimilarity indices should be interpreted with caution when the group numbers are small. This will make little difference for large groups but might have a large impact on small groups. Therefore, to compute these averages, I follow Cutler et al. (2008) and Peach (1996) and only include urban areas in which the community size of the immigrant group is greater than 500 individuals. ${ }^{16}$ For dissimilarity indices between immigrant groups and the population, the average is weighted using the immigrant community size. When the weightedaverage dissimilarity between two immigrant groups is computed, weights are the sum of the shares of the population of each group in the urban area, using only urban areas in which more than 500 members of each group live.

Table 5 reports weighted average dissimilarity indices computed at the census-tract level in 1968 and 1999. Values above the diagonal report the index for 1968, while values below the diagonal report the index for 1999.

\footnotetext{
${ }^{15}$ Urban units' definitions are those of the 1999 census. They are matched with the 1968 census using national municipality codes of municipalities within the 1999 urban areas. ${ }^{16}$ Including all urban areas slightly increases the observed dissimilarity indices for smaller groups of immigrants from Africa and Asia but does not change the results qualitatively.
} 
Table 5 : Weighted Dissimilarity between groups in 1999 (below diagonal) and 1968 (above diagonal)

\begin{tabular}{|c|c|c|c|c|c|c|c|c|}
\hline & Africa & Asia & Europe & Maghreb & Immigrants & Population & & \\
\hline Africa & $* * *$ & 0.529 & 0.414 & 0.513 & 0.457 & 0.472 & & \\
\hline Asia & 0.364 & $* * *$ & 0.427 & 0.551 & 0.418 & 0.399 & & \\
\hline Europe & 0.435 & 0.413 & $* * *$ & 0.414 & 0.339 & 0.220 & & \\
\hline Maghreb & 0.311 & 0.360 & 0.385 & $* * *$ & 0.406 & 0.430 & & \\
\hline Immigrants & 0.291 & 0.313 & 0.344 & 0.303 & $* * *$ & 0.230 & & \\
\hline Population & 0.382 & 0.382 & 0.184 & 0.381 & 0.242 & $* * *$ & & \\
\hline Population/PrivH & 0.397 & 0.402 & 0.243 & 0.365 & 0.252 & $* * *$ & & \\
\hline Population/PubH & 0.592 & 0.634 & 0.492 & 0.580 & 0.546 & $* * *$ & & \\
\hline & Algeria & Morocco & Tunisia & Italy & Spain & Portugal & Immigrants & Population \\
\hline Algeria & $* * *$ & 0.580 & 0.576 & 0.517 & 0.548 & 0.615 & 0.485 & 0.532 \\
\hline Morocco & 0.330 & $* * *$ & 0.568 & 0.586 & 0.570 & 0.685 & 0.519 & 0.543 \\
\hline Tunisia & 0.381 & 0.419 & $* * *$ & 0.496 & 0.484 & 0.686 & 0.428 & 0.428 \\
\hline Italy & 0.484 & 0.530 & 0.511 & $* * *$ & 0.369 & 0.542 & 0.300 & 0.266 \\
\hline Spain & 0.465 & 0.499 & 0.488 & 0.386 & $* * *$ & 0.546 & 0.300 & 0.309 \\
\hline Portugal & 0.450 & 0.480 & 0.517 & 0.406 & 0.397 & $* * *$ & 0.505 & 0.505 \\
\hline Immigrants & 0.301 & 0.335 & 0.313 & 0.349 & 0.330 & 0.353 & $* * *$ & 0.230 \\
\hline Population & 0.404 & 0.433 & 0.412 & 0.278 & 0.284 & 0.298 & 0.242 & $* * *$ \\
\hline Population/PrivH & 0.410 & 0.430 & 0.434 & 0.308 & 0.318 & 0.354 & 0.252 & $* * *$ \\
\hline Population/PubH & 0.582 & 0.628 & 0.631 & 0.624 & 0.627 & 0.573 & 0.546 & $* * *$ \\
\hline
\end{tabular}

Sources and Notes: 1968 and 1999 censuses. The table reports weighted average dissimilarity indexes between immigrant groups in 1968 and in 1999. Each dissimilarity index is the weighted average of dissimilarity indexes, matched over time, from French urban areas of more than 50,000 inhabitants in 1999. The column and line Population indicate dissimilarity indexes with respect to the rest of the population. The lines

Population/PrivH and Population/PubH indicate dissimilarity indexes with respect to the rest of the population for members of immigrant groups living, respectively, in public and in private housing in 1999. The column and line Immigrants indicate dissimilarity indexes with respect to all other immigrants. 
Between the two periods, the dissimilarity index of immigrants with respect to the population did not change much, increasing slightly from 0.230 in 1968 to 0.242 in 1999 . This slight increase reflects mostly the increase in the share of non-European immigrants in France, who tend to be more segregated. When measured by region or nationality, spatial segregation at the census tract level decreased substantially for most groups. For immigrants from Maghreb, the index fell from 0.430 to 0.381 between 1968 and 1999 and from 0.472 to 0.382 for Africans. Per country of origin, the index decreased by 13 percentage points for Algerians, from 0.532 to 0.404 , and by 11 percentage points for Moroccans, from 0.543 to 0.433. The segregation patterns of Tunisians are still unique among immigrants from Maghreb: while they were lower in 1968 than for other non-European groups, they declined by only 1.6 percentage points over the period, to 0.412 in 1999 . Compared to the US, these figures are strikingly low as the weighted average dissimilarity indices of immigrants reported by Cutler et al. (2008, p. 481, Table 1) are 0.46 in 1970 and 0.56 in 2000.

Differences in segregation levels with respect to the population between European and non-European immigrants are large in both years. Across groups, European immigrants have lower levels of segregation than do non-Europeans, except for immigrants from Portugal in 1968. From 1968 to 1999, the dissimilarity index of European immigrants decreased from 0.220 to 0.184 . Between the two periods, segregation levels of immigrants from Italy or Spain did not change much and stayed relatively moderate. Thus, most of this decrease is due to the decrease in segregation levels of Portuguese immigrants. Among European immigrants, the Portuguese immigrants experienced high levels of segregation in France during the 1960s. In 1968, the high segregation level of Portuguese immigrants was equivalent to the level of segregation of national groups from Maghreb and was much higher than the relatively moderate levels of segregation observed for Spanish and Italian immigrants. ${ }^{17}$ The decline in the segregation level of immigrants from Portugal over the period is thus spectacular as their segregation index in 1999 (0.298) is just slightly higher than the segregation levels of Spaniards (0.284) and Italians (0.278).

\footnotetext{
${ }^{17}$ The living conditions of Portuguese immigrants during the 1960s have been widely documented. Many Portuguese immigrants lived in ethnic slums around major French urban areas. See for example Volovitch-Tavares (1995).
} 
To highlight the impact of public housing on segregation, the final two lines of both panels report separate dissimilarity indices for public housing participants and immigrants in private housing for each group for 1999. The differences between these two groups are strikingly large. Dissimilarity indices of individuals in private housing are usually just slightly higher than segregation indices computed for the whole population. On the other hand, segregation indices for immigrants in public housing are much higher for most groups.

As noted previously, living in public housing does not affect segregation levels similarly across groups. One also observes notable differences in segregation indices across groups, confirming that public housing participants from each national group are not located in similar housing projects and that non-European immigrants tend to live in more segregated housing projects. There is a difference of more than 10 percentage points between the dissimilarity index of European immigrants in public housing and the segregation of nonEuropean immigrants in public housing. For groups of non-European immigrants that have very high rates of participation in public housing, dissimilarity indices are greater than 0.58 and are equal to 0.580 for Maghrebis and 0.631 for Tunisians, for example. These differences suggest that the concentration of non-European immigrants across housing projects is larger than the concentration of European immigrants living in public housing. Non-European immigrants tend to live in projects where they are much more isolated from the rest of the population relative to European immigrants. Notice that these relatively high segregation levels are comparable to those of Mexicans, Indians or Vietnamese in the US in 2000, which are superior to 0.56 (Cutler et al., 2008).

Because immigrants in public housing tend to live in neighborhoods with more immigrants from other groups, public housing participation might have changed the spatial distance between immigrant groups. To investigate this, the table also reports indices between specific groups to account for changes in the spatial distance between groups over time. Dissimilarity indices between groups indicate whether several groups tend to cluster together and share similar neighborhoods. These indices potentially capture an increased tendency of several immigrant groups to share the same neighborhoods.

In 1968, immigrants from Europe had the lowest level of dissimilarity with respect to other immigrant groups. Notice that, in 1968, one does not observe a particular spatial proximity among immigrants from Maghreb. The dissimilarity indices of Algerians with Moroccans and Tunisians are actually higher (0.580 and 0.576, respectively) than that with Italians (0.517) for 1968. However, for 1999, the figures suggest that immigrants from different national groups from the Maghreb tend to share the same neighborhoods: the indices 
of dissimilarity of Algerians with respect to Moroccans and Tunisians are, respectively, 0.330 and 0.381 , while the dissimilarity indices with respect to other groups are superior to 0.45 . Across regional groups, immigrants from the Maghreb also have low dissimilarity indices with other non-European immigrant groups from Asia or Africa. These results confirm that, unlike in 1968, non-European immigrants in 1999 tended to inhabit the same neighborhoods. 


\section{Conclusion}

This paper explored the evolution of immigrant segregation in France between 1968 and 1999. This paper emphasized the relationship between public housing participation and the contemporary segregation of non-European immigrants. Public housing participation in 1999 is related to an increased level of regional segregation for non-European groups, while segregation by national origin decreased over the study period.

Several new aspects of the contemporary segregation patterns emphasized in this paper deserve further research. More research is needed to explore the relationships between segregation, neighborhood characteristics and outcomes, particularly in France where the unemployment rate of immigrants is particularly large. Some research on this topic has already been done in the European context: for example, Musterd et al. (2008), using Swedish data, find large wage penalties for immigrants living in concentrated ethnic areas. Research focusing more particularly on the impact of public housing would be interesting given the large differences in housing project characteristics.

As emphasized in this paper, contemporary segregation in France is related to an increased number of nationalities across neighborhoods. The implications of the increased national diversity at the neighborhood level are widely discussed in today's academic literature because of the potential effects of neighborhoods' characteristics on social cohesion and social capital (Forest and Kearn, 2001): for Europe, Amin (2002) discusses the evolution of inter-ethnic intolerance in Britain and the conditions under which ethnic mixture might work across British cities. In a much-cited paper, Putnam (2007) provides evidence of a relation at the neighborhood level between an increase in ethnic diversity and the level of trust between inhabitants. Given the significant social difficulties in some large public housing suburbs, it would be necessary for France to evaluate the consequences of the increase in national diversity in public housing suburbs.

Finally, the role of public housing in the evolution of segregation should be better understood. As emphasized previously, there are large differences in participation rates in public housing across groups. Are they the result of discrimination in the private-sector housing market, as argued by Bouvard et al. (2009)? Further research on this topic might be helpful to design efficient housing policies. 


\section{References}

AMIN Ash, 2002, "Ethnicity and the multicultural city: living with diversity", 34 (6), pp. 959-980

AYDEMIR Abdurrahman, BORJAS George, 2006, "Attenuation Bias in Measuring the Wage Impact of Immigration", Unpublished Mimeo.

BORJAS George, 1995, "Ethnicity, Neighborhoods, and Human-Capital Externalities", American Economic Review, 85 (3), pp. 365-90.

BOUVARD Laurence, COMBES Pierre-Philippe, DECREUSE Bruno, LAOUÉNAN Morgane, SCHMUTZ Benoît, TRANNOY Alain, 2009, « Géographie du chômage des personnes d'origine africaine : Une discrimination sur le marché du logement ? », Revue Française d'Économie, 23, pp. 8-56

CHISWICK Barry R., 1978, "The effect of Americanization on the earnings of foreign-born men", The Journal of Political Economy, 86 (5), pp. 897-921

CUTLER David, GLAESER Edward, VIGDOR Jacob, 1999, "The Rise and Decline of the American Ghetto", Journal of Political Economy,107 (3), pp. 455-506.

CUTLER David, GLAESER Edward, VIGDOR Jacob, 2008, "Is the Melting Pot Still Hot? Explaining the Resurgence of Immigrant Segregation", The Review of Economics and Statistics, 90 (3), pp. 478-497.

DESPLANQUES Guy, 1996, «La répartition des personnes d'origine étrangere en France », Espaces, Populations, Sociétés, 2, pp. 287-297

DESPLANQUES Guy, TABARD Nicole, 1991, « La localisation de la population étrangère », Economie et Statistiques, 242, pp. 51-62.

DURIF Pierre, MARCHAND Olivier, 1975, « Les locataires des HLM en 1973 », Économie et Statistique, 73, pp. 3-20.

ECHENIQUE Federico, FRYER Roland, 2007, “A Measure of Segregation Based on Social Interactions”, The Quarterly Journal of Economics, 122 (2), pp. 441-485.

FARLEY Reynolds, FREY William, 1994, "Changes in the Segregation of Whites from Blacks During the 1980s: Small Steps Toward a More Integrated Society", American Sociological Review, 59 (1), pp. 23-45

FONG Eric, SHIBUYA Kumiko, 2000 (4), "The spatial separation of the poor in Canadian cities", Demography, 37, pp. 449-459.

FREY William, FARLEY Reynolds, 1996, "Latino, Asian, and Black Segregation in U.S. Metropolitan Areas: Are Multi-ethnic Metros Different?”, Demography, 33 (1), pp. 35-50. 
FORREST Ray, KEARNS Ade, 2001, "Social cohesion, social capital and the neighbourhood”, Urban Studies, 38 (12), pp. 2125-2143

JARGOWSKY Paul, 1996, "Take the Money and Run: Economic Segregation in U.S. Metropolitan Areas”, American Sociological Review, 61 (6), pp. 984-998.

LEQUIN Yves, 2006, Histoire des Étrangers et de l'Immigration en France, Paris, Larousse, $544 \mathrm{p}$.

LIPATZ Jean-Luc, 2006, «IRIS2000 : un découpage pour les statistiques infracommunales », in PUMAIN, Denise (ed.), Données Urbaines, vol. 2, Economica, Paris, pp. 21-28.

MASSEY Douglas, DENTON Nancy, 1988, “The Dimensions of Residential Segregation”, Social Forces, 67 (2), pp. 281-315.

MASSEY Douglas, FISCHER Mary, 2003, “The Geography of Inequality in the United States", 1950-2000, Brookings-Wharton Papers on Urban Affairs, 1, pp. 1 - 29.

MAURIN Éric, 2004, Le ghetto français, Paris, Seuil, 95 p.

MUSTERD Sako, 2005, "Social and ethnic segregation in Europe: levels, causes, and effects", Journal of Urban Affairs, 27 (3), pp. 331-348.

MUSTERD Sako, ANDERSSON Roger, GALSTER George, KAUPPINEN Timo, 2008, "Are immigrants' earnings influenced by the characteristics of their neighbours", Environment and Planning A., 40 (4), pp. 785-805

MUSTERD Sako, DEURLOO Marinus, 1997, "Ethnic segregation and the role of public housing in Amsterdam", Tijdschrift voor economische en sociale geografie, 88 (2), pp. 158 168.

PAN KÉ SHON Jean-Louis, 2010, “The ambivalent nature of ethnic segregation in France's disadvantaged neighbourhoods", Urban Studies, 47 (8).

PEACH Ceri, 1996, “Does Britain have ghettos?”, Transactions of the Institute of British Geographers, 21 (1), pp. 216--235

PEACH Ceri, 1999, "London and New York: contrasts in British and American models of segregation”, International Journal of Population Geography, 5 (5), pp. 319--347

PEACH Ceri, 2009, “Slippery segregation: discovering or manufacturing ghettos?”, Journal of Ethnic and Migration Studies, 35 (9), pp. 1382--1395

PINÇON Michel, 1976, Les HLM: structure sociale de la population logée. Agglomération de Paris - 1968, Paris, Centre de sociologie urbaine, 2 vol. 
PRÉTECEILLE Edmond, 2003, La Division Sociale de l'espace Francilien : Typologie socioprofesionnelle 1999 et transformation de l'espace résidentiel 1990-99, Paris, Fondation Nationale des Sciences Politiques, Centre National de la Recherche Scientifique, Observatoire Sociologique du Changement, $150 \mathrm{p}$.

PRÉTECEILLE Edmond, 2009, «La ségrégation ethno-raciale a-t-elle augmenté dans la métropole parisienne ? », Revue française de sociologie, 50 (3), pp. 489-519

PUTNAM, Robert D., 2007, "E Pluribus Unum: Diversity and community in the twenty-first century”, Scandinavian Political Studies, 30 (2), pp. 137-174

SAFI Mirna, 2009, « La dimension spatiale de l'intégration : évolution de la ségrégation des populations immigrées en France entre 1968 et 1999 », Revue française de sociologie, 50 (3), pp. 521-522

SCHOR Ralph, 1996, Histoire de l'immigration en France de la fin du XIXe siècle a nos jours, Paris, Armand Colin, 347 p.

STEBE Jean-Marc, 2007, Le logement social en France. Paris, PUF, 127 p.

VOLOVITCH-TAVARES Marie-Christine, 1995, Portugais à Champigny: le temps des baraques, Paris, Autrement, 155 p.

WACQUANT Loïc, 2007, Urban Outcasts: Stigma and Division in the Black American Ghetto and the French Urban Periphery, Cambridge, Polity Press, 360 p.

WEIL Patrick, 2005, La République et sa diversité: Immigration, intégration, discriminations, Paris, Le Seuil, 111 p.

WILSON William-Julius, 1987, The Truly Disadvantaged: The Inner City, the Underclass, and Public Policy. Chicago, University of Chicago Press, 261 p. 